\title{
CONSUMER LENDING \\ IN UKRAINE: ESTIMATION \\ OF THE EQUILIBRIUM LEVEL
}

\section{ATTILA CSAJBOK ${ }^{\mathrm{a}}$, PERVIN DADASHOVA ${ }^{\mathrm{bc}}$, PAVLO SHYKIN ${ }^{\mathrm{b}}$, BALAZS VONNAK $^{\text {d }}$}

\author{
${ }^{\text {anternational Monetary Fund }}{ }^{1}$ \\ E-mail: acsajbok@imf.org \\ ${ }^{\mathrm{b}}$ National Bank of Ukraine \\ E-mail: pervin.dadashova@bank.gov.ua \\ pavlo.shykin@bank.gov.ua \\ ${ }^{\mathrm{C}}$ National University of Kyiv-Mohyla Academy \\ ${ }^{\mathrm{d}}$ Magyar Nemzeti Bank (the Central Bank of Hungary) \\ E-mail: vonnakb@mnb.hu
}

\begin{abstract}
In line with Kiss et. al (2006), we have constructed an analytical framework for the timely detection of risks connected with the rapid growth of consumer lending, based on an econometric model for the equilibrium level of household and consumer loans. Results from an estimation on a panel of countries were extrapolated to the Ukrainian banking sector. The model suggests that after two waves of strong deleveraging starting in 2009 and in 2014, the consumer credit stock in 2019 is still well below its equilibrium level in Ukraine, despite the recent strong nominal dynamics.
\end{abstract}

JEL Codes C54, E47, G21, G38

Keywords consumer lending, equilibrium model, error-correction model, mean group estimator.

\section{INTRODUCTION}

After a period of strong deleveraging, caused by military aggression and economic crises, the volume of consumer lending has been rapidly swelling in Ukraine. Figure 1.a demonstrates the magnitude of Ukrainian household deleveraging in comparison with other countries. For the last two years, its year-on-year growth has not been lower than $30 \%$. The continued high pace of growth was sustained by a loosening of banks' lending conditions and by a rapid increase in household income. The combination of these factors promotes the realization of previously postponed demand of households and stimulates their appetite for credit.

The main driver of credit growth is small-size unsecured loans, while secured long-term mortgages form only $2 \%$ of the amount of newly issued loans. In a regional comparison, the dominance of retail loans characterizes the Ukrainian household loan portfolio (see figure 1.b). While the credit-toGDP ratio remains comparatively low, the fast accumulation of unsecured debt with a high interest rate burden puts additional risks on households, making them vulnerable to external shocks.

As the demand for credit increases, the competition between banks for new borrowers, which typically have low income in Ukraine, is very tough The necessity to maintain a strong pace of lending provokes banks to ease the underwriting criteria, which causes deterioration of the risk profile of the average borrower. As banks aspire to compensate for the arising risks by setting higher interest rates, excessive lending may lead to an increase in the debt burden for low-income households. ${ }^{2}$

These stylized facts suggest that continuing rapid growth of consumer lending in Ukraine generates a variety of potential risks that have to be managed to avoid challenges to financial stability in the medium and long run. Therefore, there is a growing need for the regulator to develop an analytical framework to analyze and detect risks related to the rapid growth of consumer lending. The primary interest is in estimating benchmarks for "normal" growth rates and levels for household indebtedness based on sound empirical foundations. Such a framework is useful not only to define the equilibrium level, but also to analyze the speed of convergence to it. This may help policymakers to manage the possible overheating of this segment by applying, in a timely manner, effective macroprudential instruments to restrict consumer lending growth.

In this paper, we derive equilibrium levels of household and consumer credit for Ukraine. For this purpose, we use a two-step approach. First, we estimate the relationship between equilibrium credit-to-GDP and the fundamentals

\footnotetext{
${ }^{1}$ At the time of the work underlying this paper, Mr. Csajbok was with the World Bank Financial Sector Advisory Center (FinSAC). FinSAC financed the technical assistance project behind this paper.

${ }^{2}$ For more details please see Box 3. "Results of a Survey of Consumer Lending by Banks: Borrowers with Low Income Are Mostly Indebted" in the Financial Stability Report of the NBU (June 2019)

(c) National Bank of Ukraine, A. Csajbok, P. Dadashova, P. Shykin, B. Vonnak, 2020. This work is licensed under a Creative Commons AttributionNonCommercial 4.0 International License. Available at https://doi.org/10.26531/vnbu2020.249.01
} 
with the Common Correlated Effect Estimator from the dataset obtained from the European Credit Research Institute (ECRI). This dataset includes data for EU-member states and nonEU advanced and emerging countries. The second step is to estimate the same relationship for Ukraine, which is done by treating the panel estimation results as prior information, and combining it with Ukrainian data using Bayes`rule.

With the estimated equilibrium credit stock for Ukraine, we also estimate short-term dynamics around the equilibrium with an error correction specification. Even if the short-term dynamics have no fundamental interpretation, they offer a useful benchmark to assess whether the actual credit growth observed in the data can be regarded as a normal convergence to the trend.

\section{LITERATURE REVIEW}

Empirical studies usually focus on the identification of excessive credit growth for particular economies. Some authors consider expansion with a growth rate higher than a particular "speed limit" as an indicator of a credit boom. For example, Duenwald et al. (2005) investigated credit booms in three countries (Romania, Bulgaria, and Ukraine) in 2000-2004. Comparing three credit boom scenarios, the authors found that the economic and institutional circumstances of each country imply different "natural" levels of such ratios and, as a result, varying paces of adjustment to them. As a result, it becomes challenging to distinguish between excessive credit growth and equilibrium movements of credit. For example, in 2001-2004, the Bulgarian credit-toGDP ratio rose on average by 7 p.p. per year (from 14.5\% in 2001 to $35.4 \%$ in 2004). The estimates of Cotarelli et al. (2005) show that such rapid growth can be identified as excessive. Before the crisis in Mexico (1994), Korea (1997), and Indonesia (1997), their credit-to-GDP growth rate was 3-5 p.p. per year. Nevertheless, banks in Bulgaria remained well-capitalized and liquid, with healthy profitability and low level of nonperforming loans in spite of ongoing credit acceleration.

Another approach is to identify the trend in credit dynamics based on univariate time-series analysis, typically smoothing with the Hodrick-Prescott filter. For example, Gourinchas et al. (2001) used the credit-to-GDP ratio, smoothened by the HP-filter, as the long-term trend. They define boom periods when credit-to-GDP is higher than the trend value plus a threshold. Such a threshold can be defined in absolute or relative terms. This approach can be applied to emerging economies with sufficiently long time series. Nakornthab et al. (2003) pointed to the necessity of long period data availability in their investigation of the credit boom in Thailand. They estimated the trend component of credit-to-GDP for the 50-year horizon (1951-2002). However, in transition economies with a comparatively short period and possible structural breaks, such as the Ukrainian one, univariate filtering may yield misleading results.

Another widely used approach is to model the relationship between the equilibrium credit-to-GDP path and its determinants. Calza et al. (2001 and 2003), used an error correction model (ECM). As explanatory variables, they choose GDP and interest rates (both short- and longterm). Boissay et al. (2005) estimated the vector error correction model (VECM) for 11 CEE countries individually. Brzoza-Brzezina (2005) used ECM with the amount of loans to the private sector and the GDP deflator as fundamental variables to estimate long-time relationships for three CEE countries independently. The pool of countries and variables chosen in the papers mentioned above was constrained by data availability and the length of the time series. To cope with this problem, Cotarelli et al. (2005), Backe et al. (2006) and Kiss et al. (2006) used panel data of various groups of countries for estimating the long-run relationship and then impose obtained estimates on CEE countries out of sample. This is the approach adopted in our estimation, too.

To exploit the information content of panel data, one has to impose cross-country restrictions on some parameters of the model. While Boissay at al. (2005) assumed common short-run dynamics, but a different long-run relationship, Kiss et al. (2006) proceeded the other way around. Following Pesaran and Smith (1995), they estimated a model with the same relationship between the credit-to-GDP ratio and economic fundamentals for all countries, and country specific short-term dynamics, with the pooled mean group estimator.

The applicability of out-of-sample estimation depends on the homogeneity between samples. Maeso-Fernandez, F., C. Osbat and Schnatz (2004) admitted that different levels of institutional and economic development between countries used for estimation and countries of interest may cause bias when extrapolating. To eliminate the problem of possible heterogeneity, the authors proposed using the mean-group estimator, which implies country-by-country estimation of the coefficients of the long-run relationship and averaging them across countries. They argue that this approach can provide consistent estimates even in the case of heterogeneity. The similar method to cope with the problem of extrapolation was used in various papers: Baltagi and Moscone (2010), Bond et al. (2010), Fleisher et al. (2010), Holly et al. (2010) and Serlenga and Shin (2007) among others.

\section{METHODOLOGY}

Our aim is to estimate the long-run relationship between certain credit aggregates and the fundamental variables explaining the permanent shifts in credit. Since most of these variables are non-stationary, the task is to find the cointegrating relationship. We label the implied credit stock as equilibrium, because the fundamental variables are related to the sustainable level of indebtedness of the private sector. As a next step, we also give an estimate of the short-run dynamics that can be used for assessing whether observed credit growth is consistent with a typical convergence to the equilibrium level.

As the Ukrainian time series on bank credit and fundamental variables are not sufficiently long enough to estimate an equilibrium relationship, we use panel estimation techniques. Our preferred estimator of the cointegrating relationship is the already mentioned CCE, which is built on the mean group estimator (Pesaran and Smith, 1995). The mean group estimator has good properties when there is heterogeneity in the slope coefficients, including the constant term, and neither the cross-section nor the time dimension of the panel is too small. ${ }^{3}$ The model can be written as

$$
y_{i t}=\beta_{i} x_{i t}+u_{i t}
$$

\footnotetext{
${ }^{3}$ The possible heterogeneity in the slope coefficients would make a conventional fixed effect model misspecified and would lead to inconsistent estimates.
} For details, see Pesaran and Smith (1995). 
where $y$ is the dependent variable (in our case the creditto-GDP ratio), $x$ is the vector of explanatory variables (in our case the "fundamental" variables), $\beta_{i}$ is the parameter vector of interest for country $i$, and $u$ is the stationary dynamics around the equilibrium. The cointegrating relationship is estimated for all individuals separately by OLS, and then the coefficient estimates are averaged to get the mean group estimator:

$$
\hat{\beta}^{M G}=\frac{1}{N} \sum_{i=1}^{N} \hat{\beta}_{i}
$$

It is important to note that although the model does not restrict the long-run relationship to be homogenous across countries, the mean group estimator is used for out-ofsample predictions because it might be more appropriate than any of the individual country estimates.

If there is a latent common factor influencing both the explanatory variables $\left(x_{i t}\right)$ and the dependent variable via $u_{i t}$, the estimator will be inconsistent due to endogeneity. Our problem is very likely to be affected by such type of endogeneity bias, as credit cycles (left-hand side) and business cycles (appearing on the right-hand side in several variables) have been synchronized to some extent within and across the countries we are going to use for the estimation. Since these common cycles do not purely reflect the causal effect of GDP on lending, but also the simultaneous effect of unobserved variables (confidence, expectations etc.) on GDP and lending, one has to control for that in order to get a consistent estimate of the long-run relationship.

This is why we used the CCE estimator of Pesaran (2006). The CCE augments the regressors used in the mean group estimation with cross-sectional averages of the dependent variable and the individual-specific regressors, and Pesaran (2006) shows that it is a consistent estimator of the slope coefficients even in the presence of common latent factors.

Having (consistent) estimates of the long-run coefficients, one can impose the same relationship for Ukraine and calculate the equilibrium level of credit by taking the appropriate linear combination of the Ukrainian fundamental variables. However, this fully out-of-sample approach may result in equilibrium estimates implausibly far from actual data. ${ }^{4}$ The main reason for this is that usually there remains lots of unexplained time-invariant heterogeneity that is captured by the country-specific constant terms.

In order to balance the huge information content of a large panel with the specific information embedded in the short Ukrainian time series, we adopted a Bayesian approach. We took the result from the panel estimation as prior information and combined it with the Ukrainian observations according to Bayes' rule to get the posterior distribution of the parameters of interest. More specifically, we use normal-inverse-gamma conjugate prior where the conditional distribution of the coefficients is multivariate normal with the mean being equal to the panel estimates of the coefficients $\left(\hat{\beta}^{M G}\right)$ and the covariance matrix being equal to the panel estimate of the coefficients' covariance matrix $\left(\widehat{\Sigma}^{M G}\right)$, that is:

$$
\beta \mid \sigma^{2} \sim \mathcal{N}\left(\hat{\beta}^{M G}, \hat{\Sigma}^{M G}\right)
$$

where

$$
\sigma^{2}\left(X^{\prime} X\right)^{-1}=\hat{\Sigma}^{M G}
$$

and $\sigma^{2}$ has an inverse gamma distribution ( $X$ is the stacked matrix of the panel explanatory variables). Then, the posterior distribution of the coefficient vector is from the Student's $t$ distribution family with analytically computable moments. ${ }^{5}$

Finally, when we derive the equilibrium path of the credit stock, we use the Hodrick-Prescott trend of fundamental variables, because they may contain short-term fluctuations that do not reflect changes in "sustainable" or "equilibrium" level of credit. The final estimate of the equilibrium is given by

$$
l_{t}^{e q}=\sum_{k} \beta_{k}^{p o s t} \tilde{x}_{t}^{k}
$$

where $l_{t}^{e q}$ is the equilibrium level of the logarithm of the credit-to-GDP ratio at period $t, \beta_{k}^{\text {post }}$-s are the Bayesian mean coefficient estimates, and $\tilde{x}^{k}$-s are the smoothened fundamental variables, including the constant.

In the next stage, we used the panel data set again to estimate a typical speed of convergence to the equilibrium level. First, we calculated the (Bayesian) equilibrium levels for each country in the panel, as explained above. ${ }^{6}$ Then we estimated a standard error correction model (ECM) of the following form:

$$
\begin{aligned}
\Delta l_{t}= & -\varphi\left(l_{t-1}-l_{t-1}^{e q}\right)+\alpha_{l} \Delta l_{t-1} \\
& +\sum_{k} \alpha_{k} \Delta x_{t-1}^{k}+c,
\end{aligned}
$$

The change in the credit stock is partly determined by how far it is from the equilibrium level, represented by the first term on the right-hand side. The so-called "speed of adjustment" coefficient $(\varphi)$ is normally positive, implying that if the credit-to-GDP ratio is lower than the equilibrium level, lending typically catches up and the gap will be closed. We estimated the parameters by OLS from the pooled sample.

\section{VARIABLES AND DATA}

We are primarily interested in the equilibrium level of consumer credit. However, there is some degree of substitutability between consumer and housing loans, and the share of consumer and housing loans within total household debts can be influenced by several unobservable factors. Thus, the equilibrium level of total household debt and the distance of the actual level from it can be sometimes as informative as the consumer credit gap itself, even if one tries to assess the sustainability of the dynamics of the latter. For this reason, we estimate our models to both credit categories (total household loans and consumer loans only).

\footnotetext{
${ }^{4}$ First, we experimented with this approach, but the implied equilibrium credit path was significantly lower in each period than the actual data for Ukraine.

${ }^{5}$ For further details see the third chapter of Walter and Augustin (2009).

${ }^{6}$ In this way, we took individual country data twice into account, because they are all included in the panel estimation as well. However, that would not result in much difference from re-estimating the panel model by dropping each country one-by-one because of their large number.
} 
We worked with a panel of yearly data of 30 countries spanning from 1995 to 2007. The dependent variable in both cases is the corresponding credit stock divided by nominal GDP. The explanatory or "fundamental" variables were chosen based on some theoretical considerations, as well as the existing empirical literature (e.g. Cottarelli et al, 2005; Égert et al, 2006; Kiss et al, 2006).

One of the most important and usually statistically significant explanatory variables is the country's development, as measured by per capita GDP. The idea is that when an economy is more developed, the role of financial intermediation is more important, resulting in a larger outstanding stock of loans.

The interest rate is another standard explanatory variable in the literature. Without borrowing constraints, it is the real interest rate that matters first of all. In reality, banks are unwilling to lend to the extent that would increase the probability of default too much. This risk is usually contained by limiting the payment-to-income ratio, which depends on the nominal interest rate. Therefore, we decomposed the nominal interest rate into real interest rate and consumer price inflation and used both variables in the regression. We used long-term interest rates because they reflect lending rates in the real economy more accurately than short-term rates, e.g. overnight interbank rates.

The share of consumption in total GDP may depend on time preferences or other structural factors (like demographic features) that can affect the equilibrium credit stock. This is particularly relevant when one investigates consumer lending, and therefore we include it, as in Gersl and Seidler (2011)

We also experimented with other candidates to explain the long-term credit stock that are justified either theoretically or empirically. These candidates included the share of young cohorts in the population, the disposable income-toGDP ratio, both appearing in Lang and Welz (2018). These variables proved to be insignificant. We could not use measures of income inequality, another potential candidate variable, because the available time series were too short to fit our panel data set.

Sectoral credit data is taken from the commercially available dataset compiled by the ECRI. The household credit is divided into three categories there: housing loans, consumer credit and other loans. The distinction between housing and consumer loans is based on the purpose of the loan. Housing and consumer loans are thus defined as the amount of loans at the end of the year granted by the resident MFI sector to resident households and to nonprofit institutions serving households (NPISHs) for housing and consumption purposes, respectively. Other loans are those other than for consumer credit and for home-buying extended to households and NPISHs for special purposes such as business needs, the procurement of office equipment, debt consolidation, education, the purchase of securities, etc. All the credit data show the stock at the end of the year and is divided by the nominal GDP in the same year.

The ECRI dataset spans the time period from 1995 to 2017 and covers all the EU member states, plus a number of non-EU advanced and emerging countries. In our sample, we included all the EU member states plus Norway, Iceland, Switzerland, the U.S., Canada, Japan, Australia, Mexico and India. Altogether 30 countries and more than 500 observations were included in the sample. The choice of countries was based on the availability of long-enough time series.

Per capita GDP, the consumption-to-GDP ratio and consumer price inflation data were taken from the ECRI database, too. The source of the long-term interest rate is the OECD database, which contains time series of government bond yields of 10-year maturity.

\section{RESULTS AND DISCUSSION}

The first step is the estimation of the long-run relationship between the credit stock and the explanatory variables from the panel data using the cross-correlated effect estimator. We experimented with total household loans, the narrow definition of consumer credit, and the broad definition that is the sum of the latter and other loans. With the broad definition, we obtained more significant estimates at the first stage than with the narrow one. Therefore in what follows, we will present results for total household credit and the sum of consumer credit and other loans (which we label simply as "consumer credit"). Table 1 shows the results of the two loan categories.

The development of the economy is positively related to the depth of financial intermediation, as expected. A one percent increase in the per capita GDP is typically accompanied by almost two percent more household creditto-GDP. This relationship is highly significant. According to the second column, the same relationship with consumer credit is much weaker and not significant. This may be a reflection of the stylized fact that in more developed countries, the share of housing loans is higher. Another factor to mention is that consumer credit data presumably contain more noise.

The consumption-to-GDP ratio is highly significant in both regressions. Its impact seems to be larger on total household credit than on consumer loans. The interpretation is the following: in countries and time periods with one percentage point higher than the consumption-to-GDP ratio, the equilibrium household (consumer) credit-to-GDP ratio is 4.5 (3.6) percent higher.

Neither the real interest rate, nor the inflation is significant in either regression. Still, we kept them in the model as they are standard explanatory variables in similar empirical studies and their sign and magnitude is plausible in each specification. The similar coefficient estimates suggest that it is their sum, the nominal interest rate that really matters in equilibrium. ${ }^{7}$ According to the coefficient estimates, it can be said that a one percentage point permanent increase in the long-term nominal interest rate reduces the household (consumer) credit-to-GDP ratio by one (one and a half) percent.

The huge standard error of the estimated constant indicates extreme uncertainty in the level of equilibrium credit. For example, the 2.6 in the case of the consumer loans means that the upper bound of the two standard error

\footnotetext{
${ }^{7}$ This is indeed reflected in the results of an alternative (restricted) specification where we used the nominal interest rate instead of the real interest rate and inflation, and the estimated parameter turned out to be significant
} 
wide confidence band is more than 13 times larger than the point estimate and more than 180 times larger than the lower bound if we look at only the error of the estimated constant. ${ }^{8}$ This is a possible consequence of the fact that there may be many country-specific factors that we could not control for in our regression. This problem is raised explicitly in Kiss et al (2006) and justifies using a Bayesian update of the panel mean group estimates at a later stage.

The chi-square statistics measure the joint significance of the estimated coefficients and thus can be interpreted as the relevance of our models. The joint significance is high in both cases, especially in the model for total household credit. This fact, and the multicollinearity of the explanatory variables, reflected in large standard errors and low individual statistical significance, motivated us to keep seemingly insignificant variables, like real interest rate, inflation, and in the case of consumer loans, per capita GDP.

As a next step, we derived the country specific Bayesian posterior estimates treating the panel regression result as a prior. Using the posterior mean coefficient estimates and the Hodrick-Prescott trend of the fundamental variables, we calculated the evolution of the credit gap (percentage distance from the equilibrium) for each country.

The dynamics of the credit gaps can be statistically modelled by an error correction specification. It relates the change in the credit-to-GDP ratio to the credit gap and the lagged changes in the dependent and explanatory variables. Table 2 lists the most important statistics of the pooled OLS estimation.

The explanatory power of the regressions is reasonably high, the estimated coefficients are jointly significant at all conventional levels. ${ }^{9}$

The estimated speed of adjustment to equilibrium, which is the coefficient of the error correction term, is similar for both credit categories. Its value is roughly 0.12 , meaning that the driving force towards the equilibrium per se can reduce the credit gap by 12 percent in one year. However, the total speed of adjustment is affected by the lagged dynamics of all variables. Based on the estimated coefficients and their significance, the most important lagged determinant is the change of the credit-to-GDP ratio in the previous year. The value above 0.5 indicates substantial inertia. The persistence in trend has implications for the adjustment dynamics too. If, for instance, the credit stock is above the equilibrium level and is growing at a high pace, the trend inertia may completely offset the attraction of the equilibrium quantified by the "speed of adjustment" coefficient of the error correction term. In contrast, when the gap is closing, the total speed of adjustment can be faster than one implied by the value of 0.12 , because the trend of the previous period adds to the normal error correction mechanism.
Having obtained all the panel estimates of short- and long-term credit dynamics, we can calculate the equilibrium level of credit in Ukraine, as well as the expected adjustment dynamics. We obtained the long-term coefficients by combining the pooled mean group estimates with the Ukrainian data using Bayes' rule. Then we derived the equilibrium credit stock using these coefficients and the Hodrick-Prescott smoothened time series of the Ukrainian fundamental variables. We also used their forecasted values. The forecast was based on the inflation report of the NBU (January 2019). ${ }^{10}$

Figure 2 depicts the evolution of Ukrainian (a) household and (b) consumer credit-to-GDP ratio, which consists of the estimated equilibrium paths with confidence bands based on two standard errors in each direction. Values denoted by a solid bright-green line are forecast based on the error correction estimates.

Our equilibrium models are written in terms of creditto-GDP ratios. However, the focus of policymakers is often on growth rates of credit rather than on credit-to-GDP. The original concerns in Ukraine were about the close to 30 percent nominal growth rate of the net (of provisions) consumer credit. In order to put these growth figures in the context of our equilibrium model, we applied an official NBU projection of a roughly 30 percent nominal growth rate of net consumer loans. The projections are shown in Figure 2, together with a 95 percent confidence interval constructed around the estimated adjustment path. ${ }^{11}$ As can be seen, a continued 30 percent nominal growth of consumer loans in the next two years would represent a somewhat faster increase than what is implied by the estimated adjustment path. However, even with this high nominal growth rate, consumer credit-to-GDP would remain within the 95 percent confidence interval of the estimated adjustment path.

Although theoretically the estimated adjustment path and the confidence interval around it do not say much about equilibrium dynamics (rather they represent the average speed of adjustment in the panel sample), they may provide a useful benchmark to assess credit dynamics before credit reaches and possibly goes above the estimated equilibrium level.

\section{CONCLUSION}

The main story is independent of whether we look at the consumer loans or the total household loans, only the magnitudes are different. There was rapid credit growth between 2006 and 2009 (at the beginning of our Ukrainian sample), with the stock being roughly twice as much as the estimated equilibrium. The boom stopped abruptly, and household indebtedness dropped dramatically, reaching the estimated equilibrium by 2012-2013. Starting from 2014, there was a second wave of contraction in lending, and the credit stock fell well below the equilibrium. By 2017, the credit gap reached minus 60-70 percent.

\footnotetext{
${ }^{8}$ Of course, the total error of our regression can be much smaller, because the error of the constant can be correlated with those of other coefficients estimates in a way that they offset each other to some extent.

${ }^{9}$ In an alternative specification, we also estimated the short-term dynamics using the short-term interest rate (instead of the long one). These results are very close to those of the original specification, namely, it is only the distance from the equilibrium (ECM term) and the lagged first difference of the credit stock that matters. All the other coefficients were negligible, insignificant. The value of the first two coefficients changed only slightly.

${ }^{10}$ When forecasting the GDP, we used the NBU's forecast of potential GDP instead of the headline. We assumed that the population and the consumption share will not change in the next three years. We also took the NBU's inflation forecast as given.

${ }^{11}$ The confidence interval around the adjustment path cannot be derived analytically. We constructed it by doing simulations, taking 10,000 draws from the joint distribution of the estimated parameters (assumed to be normally distributed) combined with draws from the distribution of the residuals (also assumed to be normal) for each forecasting horizon. The 2.5 and 97.5 percentiles of the resulting forecast distributions gave us the lower and upper bounds of the 95 percent confidence interval.
} 
According to our forecast, the turnaround is expected to take place slowly. The reason is the above-mentioned inertia in the trend, which implies that even if the gap is negative, the decreasing trend of the previous years may partly or fully

\section{REFERENCES}

Baltagi, B., H., Moscone, F. (2010). Health care expenditure and income in the OECD reconsidered: Evidence from panel data. Economic Modelling, 27(4), 804-811. https://doi.org/10.1016/j.econmod.2009.12.001

Backe, P., Egert, B., Zummer, T. (2006). Credit growth in Central and Eastern Europe: Emerging from financial repression to new (over) shooting stars? Working Paper Series, 687. Frankfurt am Main: European Central Bank. Retrieved from https://www.econstor.eu/ bitstream/10419/153121/1/ecbwp0687.pdf

Boissay, F., Calvo-Gonzales, O., Kozluk, T. (2005). Is lending in Central and Eastern Europe developing too fast? In Financial Development, Integration and Stability. https://doi.org/10.4337/9781847203038.00023

Bond, S., Leblebicioĝlu, A., Schiantarelli, F. (2010). Capital accumulation and growth: a new look at the empirical evidence. Journal of Applied Econometrics, 25(7), 10731099. https://doi.org/10.1002/jae.1163

Brzoza-Brzezina, M. (2005). Lending booms in the new EU member states: Will euro adoption matter? Working Paper Series, 546. Frankfurt am Main: European Central Bank. Retrieved from https://www.ecb.europa.eu/pub/pdf/ scpwps/ecbwp543.pdf

Calza, A., Gartner, C., Sousa, J. (2001). Modelling the demand for loans to the private sector in the euro area. Working Paper Series, 55. Frankfurt am Main: European Central Bank. Retrieved from https://www.ecb.europa.eu/ pub/pdf/scpwps/ecbwp055.pdf

Calza, A., Manrique, M., Sousa, J. (2003). Aggregate loans to the euro area private sector. Working Paper Series, 202. Frankfurt am Main: European Central Bank. Retrieved from https://www.ecb.europa.eu/pub/pdf/scpwps/ecbwp202.pdf

Cottarelli, C., Dell'Ariccia, G., Vladkova-Hollar, I. (2005). Early birds, late risers, and sleeping beauties: Bank credit growth to the private sector in Central and Eastern Europe and in the Balkans. Journal of Banking \& Finance, 29(1), 83-104. https://doi.org/10.1016/j.jbankfin.2004.06.017

Duenwald, C., Gueorguiev, N., Schaechter, A. (2005). Too much of a good thing? Credit booms in transition economies. IMF Working Paper, 05/128. International Monetary Fund. Retrieved from https://www.imf.org/external/ pubs/ft/wp/2005/wp05128.pdf

Égert, B., Backé, P. Zumer, T. (2006). Credit growth in Central and Eastern Europe - new (over)shooting stars? Working Paper Series, 687. Frankfurt am Main: European Central Bank. Retrieved from https://www.ecb.europa.eu/ pub/pdf/scpwps/ecbwp687.pdf

Fleisher, B., Li, H., Zhao, M. Q. (2010). Human capital, economic growth, and regional inequality in China. Journal of Development Economics, 92(2), 215-231. https://doi.org/10.1016/j.jdeveco.2009.01.010 offset the mean-reverting forces. Therefore, our estimates predict a slight increase in credit-to-GDP for the following couple of years.

Gersl, A., Seidler, J. (2011). Excessive credit growth as an indicator of financial (in)stability and its use in macroprudential policy, In CNB Financial Stability Report 2010/2011, ch. Thematic Article 2, p. 112-122. Czech National Bank.

Gourinchas, P-O., Valdes, R. Landerretche, O. (2001). Lending booms: Latin America and the world. NBER Working Paper, 8249. Cambridge: National Bureau of Economic Research. Retrieved from https://www.nber.org/papers/ w8249.pdf

Holly, S., Pesaran, M. H., Yamagata, T. (2010). A spatio-temporal model of house prices in the USA. Journal of Econometrics, 158(1), 160-173. https://doi.org/10.1016/j. jeconom.2010.03.040

Kiss, G., Nagy, M. Vonnák, B. (2006). Credit growth in Central and Eastern Europe: Convergence or boom. MNB Working Papers, 2006/10. Budapest: Magyar Nemzeti Bank. Retrieved from https://www.mnb.hu/letoltes/wp2006-10.pdf

Lang, J. H., Welz, P. (2018). Semi-structural credit gap estimation. Working Paper Series, 2194. Frankfurt am Main: European Central Bank. Retrieved from https://www.ecb. europa.eu/pub/pdf/scpwps/ecb.wp2194.en.pdf

Maeso-Fernandez, F., Osbat, C., Schnatz, B. (2004). Towards the estimation of equilibrium exchange rates for CEE acceding countries: Methodological issues and a panel cointegration perspective. Working Paper Series, 353. Frankfurt am Main: European Central Bank. Retrieved from https://www.ecb.europa.eu/pub/pdf/scpwps/ecbwp353.pdf

Nakontham, D., Subhaswasdikul, M. (2003). Banking sector fundamentals: Learning from the recent bank lending contraction. Bank of Thailand Discussion Paper, January 2003.

Pesaran, M. H., Smith, R. P. (1995). Estimating long-run relationships from dynamic heterogeneous panels. Journal of Econometrics, 68, 79-113. https://doi.org/10.1016/03044076(94)01644-F

Pesaran, M. H. (2006). Estimation and inference in large heterogeneous panels with a multifactor error structure. Econometrica, 74(4), 967-1012. https://www.jstor. org/stable/3805914

Serlenga, L., Shin, Y. (2007). Gravity models of intra-EU trade: Application of the CCEP-HT estimation in heterogeneous panels with unobserved common time-specific factors. Journal of Applied Econometrics, 22(2), 361-381. https://doi.org/10.1002/jae.944 


\section{APPENDIX A. TABLES}

Table 1. Estimated Relationship between Equilibrium Credit Stock and its Fundamentals

\begin{tabular}{|c|c|c|}
\hline & \multicolumn{2}{|c|}{ Dependent variable } \\
\hline & $\Delta \log ($ Household credit to GDP) & $\Delta \log ($ Consumer credit to GDP) \\
\hline \multirow[t]{2}{*}{$\log ($ Per capita GDP) } & $1.848^{* *}$ & 0.237 \\
\hline & $(0.346)$ & $(0.448)$ \\
\hline \multirow[t]{2}{*}{$\mathrm{C} / \mathrm{Y}$} & $4.520^{* * *}$ & $3.601^{* *}$ \\
\hline & $(1.033)$ & $(1.452)$ \\
\hline \multirow[t]{2}{*}{ Real interest rate } & -0.010 & -0.017 \\
\hline & $(0.015)$ & $(0.002)$ \\
\hline \multirow[t]{2}{*}{ Inflation } & -0.011 & -0.014 \\
\hline & $(0.014)$ & $(0.022)$ \\
\hline \multirow[t]{2}{*}{ Constant } & -3.911 & 2.382 \\
\hline & $(2.160)$ & $(2.600)$ \\
\hline $\mathrm{N}$ & 571 & 484 \\
\hline Number of groups & 30 & 26 \\
\hline Wald chi-square (4) & $32.870^{* * *}$ & $10.750^{* * *}$ \\
\hline Wald $p$-value & 0.000 & 0.030 \\
\hline
\end{tabular}

Table 2. Panel Estimates of Short-Term Dynamics Around the Equilibrium

\begin{tabular}{|c|c|c|c|}
\hline & & \multicolumn{2}{|c|}{ Dependent variable } \\
\hline & & $\Delta \log ($ Household credit to GDP) & $\Delta \log ($ Consumer credit to GDP) \\
\hline & Error correction term & $0.117^{* * *}$ & $0.120^{* * *}$ \\
\hline & & $(0.012)$ & $(0.015)$ \\
\hline & Lagged dependent & $0.579^{* * *}$ & $0.556^{* * *}$ \\
\hline & & $(0.028)$ & $(0.035)$ \\
\hline \multirow{10}{*}{$\begin{array}{l}\text { First difference of lagged } \\
\text { explanatory variables }\end{array}$} & \multirow[t]{2}{*}{$\log ($ Per capita GDP) } & 0.010 & 0.220 \\
\hline & & (0.094) & $(0.133)$ \\
\hline & \multirow[t]{2}{*}{$\mathrm{C} / \mathrm{Y}$} & -0.234 & -0.098 \\
\hline & & $(0.308)$ & $(0.468)$ \\
\hline & \multirow[t]{2}{*}{ Real interest rate } & 0.000 & 0.004 \\
\hline & & $(0.002)$ & $(0.003)$ \\
\hline & \multirow[t]{2}{*}{ Inflation } & 0.003 & $0.009^{* * *}$ \\
\hline & & $(0.002)$ & $(0.003)$ \\
\hline & \multirow[t]{2}{*}{ Constant } & $0.012^{* * *}$ & 0.000 \\
\hline & & $(0.003)$ & $(0.004)$ \\
\hline & $\mathrm{N}$ & 511 & 432 \\
\hline & R-squared & 0.609 & 0.490 \\
\hline & Wald F(6, \# obs-7) & $130.780^{* * *}$ & $68.130^{* * *}$ \\
\hline & Wald $p$-value & 0.000 & 0.000 \\
\hline
\end{tabular}

$p$-values ${ }^{*} p<0.1 ;{ }^{* *} p<0.05 ;{ }^{* * *} p<0.01$

Note: Standard errors are in parentheses. 


\section{APPENDIX B. FIGURES}

(a) Consumer Loans** to GDP Ratio

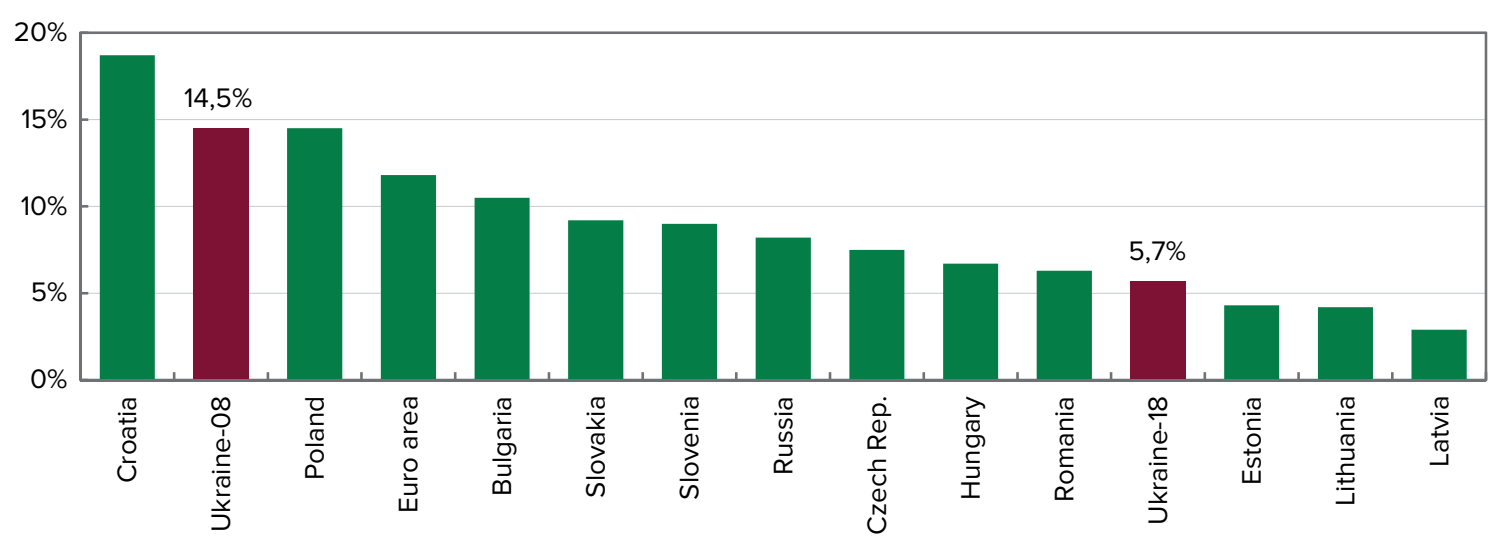

(b) Fraction of Consumer Loans ${ }^{* *}$ in Total Portfolio

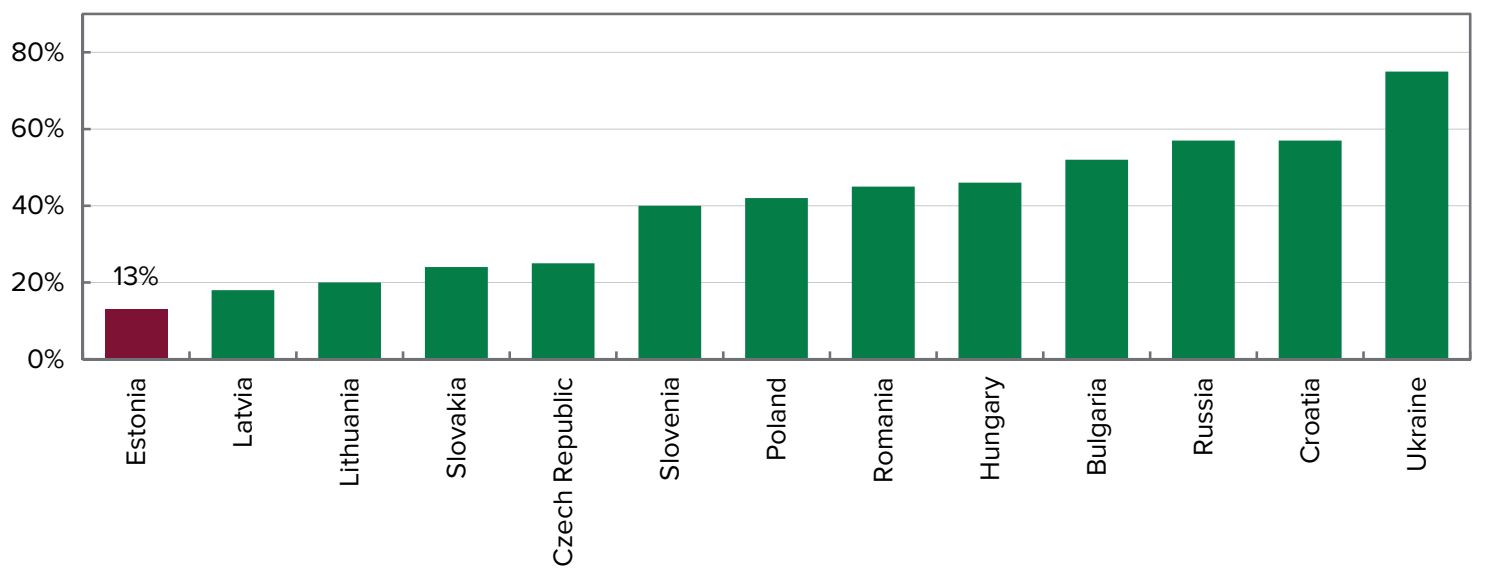

Figure 1. Characteristics of Consumer Loans by Region

*as of 1 October 2018

${ }^{* *}$ For Ukraine - gross consumer and other loans (except for loans for buying and reconstructing property) 
(a) Household Loans

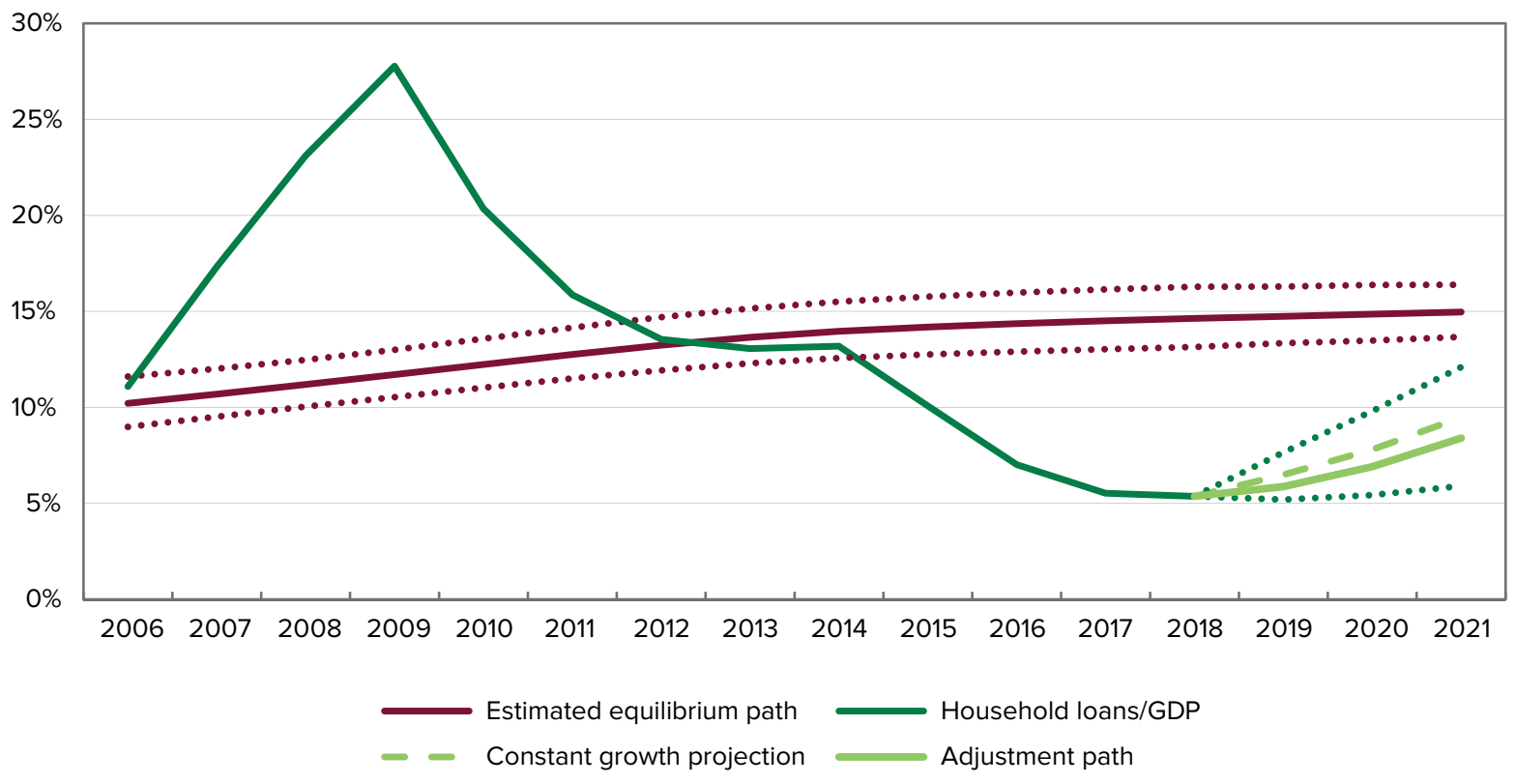

(b) Consumer Loans

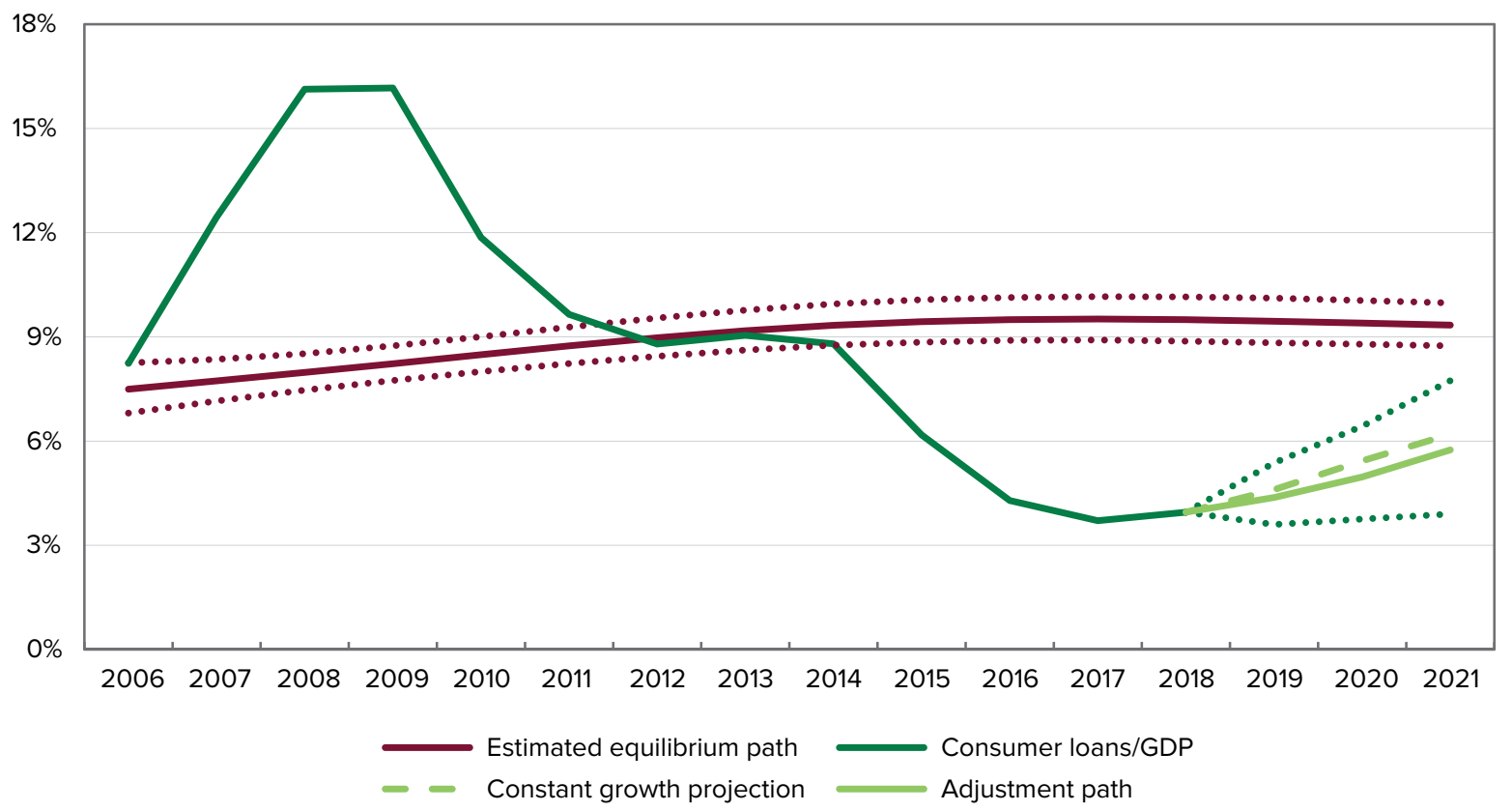

Figure 2. Projections of Household Loan Dynamics Assuming the Recent High Nominal Growth Rate vs. the Estimated Adjustment Path *dotted lines represent $95 \%$ of confidence bands 